Piwowarski; V. V. Hoblyk. Mukachevo - Częstochowa: MSU publ., Jan Długosz Academy, 2018. Issue 24 (1). PP. 227-230.

\title{
REFERENCES
}

1. Velykyy tlumachnyy slovnyk suchasnoyi ukrayinskoi movy [Large explanatory dictionary of the modern Ukrainian language]. Uklad. V. T. Busel. Kyiv-Irpen, Perun, 2002. 1440 s.

2. Danylenko L. Osnovni napryamy rozvytku menedzhmentu osvitnikh innovatsiy [The main directions of development of educational innovation management]. Menedzhment innovatsiy v osviti. Kyiv: Shkilnyi svit, 2007. S. 82-95.

3. Druker P. F. Effektivnyy rukovoditel [Effective leader]. M., 2007. $224 \mathrm{~s}$.

4. Luniachek V. E. Pedahohichnyy menedzhment: navch. posibnyk [Pedagogical management: a textbook]. Kharkiv: Mahistr, 2015. $512 \mathrm{~s}$.

5. Nyemets L. M., Sehida K. Yu., Lohvynova M. O. Pedahohichnyy menedzhment: navch.-metodychnyy posibnyk dlia studentiv pershoho kursu mahistratury spetsialnosti 014.07. Serednya osvita (Heohrafiya) [Pedagogical management: a textbook]. Kharkiv, 2019. $86 \mathrm{~s}$.

6. Osvitniy menedzhment: navch. posibnyk [Educational management]. Za zah. redaktsiyeyu L. I. Danylenko, L. M. Karamushky. Kyiv, Shkilnyi svit, 2003. 400 s.

7. Palinchak V. Do pytannia pro vyznachennia poniattia "menedzhment" naukovtsiamy Ukrainy i USA. Naukovyi visnyk Uzhhorodskoho natsionalnoho universytetu. Seriia: Pedahohika. Sotsialna robota [On the question of defining the concept of «management» by scientists from Ukraine and the United States]. Naukovyy visnyk Uzhhorods'koho natsional'noho universytetu. Seriya: Pedahohika. Sotsialna robota. 2014. Vol. 32. S. 143-144.

8. Pedahohika vyshchoyi shkoly: navch. posibnyk [Pedagogy of high school]. Za red. Z. N. Kurlyand. Kiev, Znannia, 2005. $399 \mathrm{~s}$.

9. Piddubna L. I., Shestakova O. A. "Tekhnolohizatsiia" konkurentospromozhnosti: teoretykometodolohichni aspekty ["Technologization" of competitiveness: theoretical and methodological aspects]. Mekhanizm rehuliuvannia ekonomiky. 2012. Vol. 1. S. 1-9.

10. Rayzberg B. A. Lozovskiy L. Sh., Starobubtseva E. B. Sovremennyy ekonomicheskiy slovar (1200 terminov) [Modern economic dictionary (1200 terms)]. M., INFRA, 2000. $480 \mathrm{~s}$.

11. Rozenberg Dzh. Biznes i menedzhment. Terminologicheskii slovar [Business and management. Terminological dictionary]. M.: INFRA, 1997. $464 \mathrm{~s}$.

12. Simonov V. P. Pedagogicheskiy menedzhment. Nou-khau v obrazovanii: ucheb. posobie [Pedagogical management. Know-how in education]. M., Yurayt Izdat, 2009. 357 s.

13. Tekhnolohia [Technology]. URL: https://uk.wikipedia.orh/wiki/Tekhnolohiya.

14. Tulenkov M. Kontseptualizatsiia poniat "menedzhment" i "upravlinnia" v suchasnomu naukovomu dyskursi. [Conceptualization of the concepts of "management" and "management" in modern scientific discourse]. Politychnyy menedzhment. 2011. Vol. 3. S. 101-111.

15. Usatenko V. M. Kontseptualni pidkhody do tekhnolohizatsii upravlinnia rozvytkom orhanizatsiinoi kultury zakladu zahalnoi serednoi osvity [Conceptual approaches to the technologicalization of management of the development of organizational culture of general secondary education]. Visnyk Chernihivskoho natsionalnoho pedahohichnoho universytetu. Seriia: Pedahohichni nauky. 2018. Vol. 150. S. $140-145$.

16. Oxford English Dictionary, second edition, edited by John Simpson and Edmund Weiner, Clarendon Press, 1989.

17. Shvardak M. Modern technologies of management of educational establishments. International scientific journal "Education and science". Mukachevo-Częstochowa, MSU publ., Jan Długosz Academy. 2018. Vol. 24 (1). PP. 227-230.

УДК 378.174

DOI 10.25128/2415-3605.20.2.22

\section{ІРИНА ПРОЦЕНКО}

ORCID: 0000-0003-1792-7200 procenkoira83@ukr.net кандидат педагогічних наук, доцент Сумський державний педагогічний університет імені А. С. Макаренка вул. Роменська, 87, м. Суми 


\section{ДОСЛІДЖЕННЯ ОБІЗНАНОСТІ КЕРІВНИКІВ ОСВІТНІХ ЗАКЛАДІВ ЩОДО ПРОБЛЕМИ УПРАВЛІННЯ ПРОФЕСІЙНОЮ АДАПТАЦІЕЮ ВЧИТЕЛІВ}

В умовах значних сочіально-економічних, політичних та інформаційно-технологічних змін, щзо відбуваються нині в Україні, проблема адаптаиії особистості виступає на периий план. Це є суттєвим i для діяльності освітніх організачій, які повинні швидко реагувати на виклики сьогодення, вносити необхідні зміни у зміст навчання, знаходити і застосовувати нові форми взаємодії, оскільки працюють $з$ молодим поколінням, яке є більш відкритим до усього нового $i$ швидше, порівняно з дорослими, адаптується до змін у суспільстві. Водночас необхідність введення змін у професійну діяльність вчителів та управлінську (менеджерську) діяльність керівників навчальних закладів згідно з новими сочіальними і педагогічними вимогами свідчтьь, щуо управління професійною адаптачією вчителів треба розглядати як актуальний напрямок психологічного дослідження і практики. Нова суспільна реальність вимагає розробки нових підходів до психологічної підготовки керівників освітніх організацій, зумовлює актуальність підвищення їх професійної компетентності, зокрема, з психологічних основ управління професійною адаптацією вчителів, врахування зовнішніх і внутрішніх чинників, які впливають на цей nрочес.

Ключові слова: освітні заклади, управління, зовнішні та внутрішні чинники, адаптація вчителя, професійна адаптація.

ИРИНА ПРОЦЕНКО

кандидат педагогических наук, доцент Сумский государственный педагогический университет имени А. С. Макаренко ул. Роменская, 87, г. Сумы

\section{ИССЛЕДОВАНИЕ ОСВЕДОМЛЕННОСТИ РУКОВОДИТЕЛЕЙ УЧЕБНЫХ ЗАВЕДЕНИЙ О ПРОБЛЕМАХ УПРАВЛЕНИЯ ПРОФЕССИОНАЛЬНОЙ АДАПТАЦИЕЙ УЧИТЕЛЕЙ}

В условиях значительных сочиально-экономических, политических и информационнотехнологических изменений сегодня в Украине проблема адаптации личности выступает на первый план. Это существенно и для деятельности учебных организаций, которые должны быстро реагировать на современные вызовы в обществе, вносить необходимые изменения в содержание обучения, находить и внедрять новые формы взаимодействия, поскольку они работают з молодым поколением, которое больше открыто ко всему новому и быстрее, чем взрослые, адаптируется $к$ общественным изменениям. Одновременно необходимость введения изменений в профессиональную деятельность учителей и управленческую (менеджерскую) деятельность руководителей учебных заведений в соответствии с новыми сочиальными и педагогическими требованиями свидетельствует, что управление профессиональной адаптацией учителей необходимо рассматривать как актуальное направление психологическо-педагогического исследования и практики. Новая общественная реальность требует разработки новых подходов к психологической подготовке руководителей образовательных организачий, обуславливает актуальность повымения их профессиональной компетентности, 6 частности, из психологических основ управления профессиональной адаптацией учителей, учета внешних и внутренних факторов, которые влияют на указанный прочесс.

Ключевые слова: учебные заведения, управление, внешние и внутренние факторы, адаптация учителя, профессиональная адаптация.

IRYNA PROTSENKO

Candidate of Pedagogical Sciences, Associate Professor Sumy State A. S. Makarenko Pedagogical University

87 Romenska Str., Sumy

\section{RESEARCH OF AWARENESS OF PRINCIPALS OF EDUCATIONAL INSTITUTIONS REGARDING THE PROBLEM OF MANAGEMENT OF PROFESSIONAL ADAPTATION OF TEACHERS}

In the context of significant socio-economic and information-technological changes taking place in our country today, the problem of personal adaptation comes to the fore. This is essential for the activities of 
educational organizations, which must also respond quickly to social changes in society, make the necessary changes in the content of education, find new forms of interaction, as they work with the younger generation, which is more open to everything new and considerably faster adapt to social change in comparison with adults. However, the need for changes in the professional activities of teachers and managerial activities of school principals in accordance with the new social requirements suggest that the management of professional adaptation of teachers should be considered as an important area of psychological research. In addition, the new social conditions require the development of new approaches to psychological training of principals of educational organizations, necessitate increasing their psychological competence, in particular, in the field of psychological foundations of teacher professional adaptation management, taking into account external and internal factors influencing this process.

The following theoretical methods were used in the research process: analysis of philosophical, managerial, psychological-pedagogical domestic and foreign pedagogical literature on the research topic to find out the state of development of the problem; empirical: questionnaires. Thus, the data obtained, in our opinion, indicate an insufficient level of psychological training of school leaders on the problems of management of professional adaptation, and the need to implement a special program in this area of management in the institutions of postgraduate pedagogical education.

Keywords: educational institutions, external and internal factors, teacher adaptation, professional adaptation.

Сучасні виклики суспільства вимагають нового рівня розуміння теорії і практики управління освітніми системами. У зв'язку з цим виникає необхідність розробки сучасних підходів, технологій і механізмів управління навчальним процесом. Сьогодні бажання, старанності і відданості гарного керівника XX н.. вже недостатньо. Мова йде про якісно новий рівень компетентності, якісно нову підготовку кадрів на керівні посади. За умов суттєвих змін у нашій країні сьогодні проблема адаптації особистості є однією з найбільш актуальних. Це суттєво і для освітніх установ, які повинні швидко реагувати на запити суспільства у підготовці майбутніх фахівців, зокрема, у сфері підготовки керівників навчальних закладів.

Питання адаптації молодих фахівців до професійної діяльності займають важливе місце в психолого-педагогічній літературі. Проблемами психологічної адаптації до професійної діяльності у закладах середньої освіти вивчали М. Бурда, С. Гончаренко, І. Зязюн, О. Савченко та інші науковці. За останні десятиліття значну увагу приділяють підвищенню кваліфікації професійної компетентності фахівців різних галузей у зв'язку 3 гострою потребою кваліфікованих кадрів, здатних до творчої праці та професійного розвитку. Підтвердженням цього $\epsilon$ педагогічні праці Т. Добудько, Н. Лобанової, М. Лук'янової, А. Маркової, Л. Паращенко, В. Сєрова, Е. Соф'янца, Л. Хоружої, Є. Шиянова. Психологічні проблеми адаптації вчителів до роботи у школі вивчали I. Бех, Дж. Брунер, Н. Лукашевич, С. Максименко, О. Мороз, О. Солодухова, Н. Чайкіна та ін.

Мета статті - дослідити стан обізнаності керівників освітніх закладів щодо проблеми управління професійною адаптацією вчителів.

Для 3'ясування рівня психологічної компетентності керівників освітніх закладів 3 проблем управління професійної адаптації вчителів й особливостей їх управлінської діяльності, які впливають на успішність такої адаптації, нами було проведено дослідження, у процесі якого використовувалися методи опитування (анкетування). Воно проводилось на базі загальноосвітніх шкіл м. Суми (було охоплено 18 керівників шкіл іi 26 їх заступників). Був розроблений спеціальний опитувальник, який включав питання, спрямовані на з'ясування аналізу психологічної підготовки керівників щодо: а) сутності управління професійною адаптацією вчителів та його складових; б) розуміння особливостей професійної адаптації різних категорій вчителів (з різним педагогічним стажем), конкретніше, тих труднощів, які виникають у вчителів у процесі адаптації.

Опитувальник для вивчення компетентності керівників шкіл

щодо проблеми управління професійною адаптацією вчителів

1. Що таке професійна адаптація вчителя?

2. Назвіть, які, на вашу думку, труднощі існують у вчителів зі стажем роботи до 5 років?

3. Назвіть, які, на вашу думку, труднощі існують у вчителів зі стажем роботи 6-10 років?

4. Назвіть, які, на вашу думку, труднощі існують у вчителів зі стажем роботи 11-20 років? 
5. Назвіть, які, на вашу думку, труднощі існують у вчителів зі стажем роботи більше 21 років?

Проаналізуємо основні результати опитування, що відображені у н. .. 1-5. Насамперед звернемося до даних, які відображають особливості знань керівників освітніх закладів щодо сутності управління професійною адаптацією та іiі складових. Отримані дані були систематизовані у дві групи згідно з основними структурними елементами управління професійною адаптацією вчителів (управління професійною адаптацією вчителів та управління соціально-психологічною адаптацією вчителів).

На основі даних, представлених у н. .. 1, виявлено ряд проблем, які існують в рівні психологічної підготовки більшості керівників шкіл (понад 70,0%) до управління професійною адаптацією.

По-перше, професійна адаптація здебільшого розуміється керівниками як односторонній процес засвоєння вчителем існуючих вимог до професійної діяльності (з пристосуванням до специфічних вимог конкретної школи) і не розглядається як процес активного внесення у діяльність школи нових ідей, підходів до здійснення педагогічної діяльності. Про це, зокрема, свідчить той факт, що переважна більшість опитаних керівників шкіл $(35,6 \%)$ при розгляді сутності управління адаптацією роблять акцент на пристосуванні вчителя до освітньої організації (умов праці, керівника, педагогічного колективу, учнів, ролі вчителя та ін.).

І лише невелика кількість опитаних керівників $(3,4 \%)$ розглядають управління професійною адаптацією вчителів у контексті внесення в діяльність школи нових ідей та підходів. Тож можна зробити висновок, що в результаті такого підходу не створюються достатні умови для високого рівня активності, творчості вчителів, самовираження їх у фаховій діяльності.

По-друге, у процесі управління професійною адаптацією вчителів основна увага керівників акцентується на створенні умов для розвитку професійно-методичних й організаційно-ситуативних складових професійної адаптації і значно менше уваги приділяється іiї психологічним та соціально-психологічним складовим.

Таблиия 1

Знання керівників освітніх закладів про основні складові управління професійною адаптацією вчителів та їх сутність (у \% від загальної кількості опитаних)

\begin{tabular}{|c|c|c|c|}
\hline № & $\begin{array}{ll}\text { Складові } & \text { управління } \\
\text { професійною } & \text { адаптацією } \\
\text { вчителів } & \\
\end{array}$ & $\begin{array}{l}\text { Сутність складових управління професійною } \\
\text { адаптацією вчителів }\end{array}$ & $\%$ \\
\hline 1 & 2 & 3 & 4 \\
\hline \multicolumn{3}{|c|}{$\begin{array}{l}\text { I. Складові, які відносяться до управління власне професійною адаптацією } \\
\text { вчителів }\end{array}$} & 73.5 \\
\hline 1. & $\begin{array}{l}\text { Забезпечення пристосування } \\
\text { вчителя до освітньої } \\
\text { організації та та ролі } \\
\text { педагогічного працівника }\end{array}$ & $\begin{array}{l}\text { Забезпечення пристосування вчителя до умов } \\
\text { роботи у школі, до керівника, до колективу, до } \\
\text { учнів; забезпечення пристосування до викладання } \\
\text { предмету; низької державної оцінки праці вчителя; } \\
\text { позиції вчителя, згідно потреб суспільства; до } \\
\text { нових сучасних умов. }\end{array}$ & 35,6 \\
\hline 2. & $\begin{array}{lr}\text { Створення умов } & \text { для } \\
\text { досягнення необхідного } \\
\text { професійного } & \text { та } \\
\text { методичного рівня } & \text { роботи } \\
\text { вчителя } & \end{array}$ & $\begin{array}{l}\text { Створення } \text { умов для оволодіння вчителем } \\
\text { знаннями по предмету, навчальним матеріалом та } \\
\text { доведення його до учнів у дохідливій формі; } \\
\text { оволодіння методикою викладання предмету; } \\
\text { реалізація диференційованого підходу до } \\
\text { навчання; розуміння свого призначення; та } \\
\text { відповідальності за формування особистості учня. }\end{array}$ & 19,8 \\
\hline 3. & $\begin{array}{l}\text { Забезпечення розвитку } \\
\text { організаційно-ситуативних } \\
\text { вмінь вчителя }\end{array}$ & $\begin{array}{l}\text { Забезпечення розвитку у вчителів вмінь, які дають } \\
\text { можливість вільно вести себе у різних ситуаціях; } \\
\text { досягати поставленої мети у будь-якій ситуації; } \\
\text { швидко пристосовуватися до нових керівників, їх } \\
\text { вимог та розпоряджень; вміння вільно вести себе у } \\
\text { будь-якій ситуації. }\end{array}$ & 14,7 \\
\hline
\end{tabular}




\section{МЕДЖМЕНТ ОСВІТИ}

\begin{tabular}{|c|c|c|c|}
\hline 4. & $\begin{array}{l}\text { Забезпечення умов } \\
\text { внесення для } \\
\text { підходів }\end{array}$ & $\begin{array}{l}\text { Створення умов для орієнтації вчителя на нові } \\
\text { підходи, бажання змінити щось у школі, внести } \\
\text { новий «імпульс». }\end{array}$ & 3,4 \\
\hline \multicolumn{3}{|c|}{$\begin{array}{l}\text { II. Складові, які відносяться до управління соціально-психологічною адаптацією } \\
\text { вчителів }\end{array}$} & 26,5 \\
\hline 1. & $\begin{array}{lr}\text { Створення } & \text { умов для } \\
\text { ефективного } & \text { спілкування } \\
\text { вчителів та } & \text { формування } \\
\text { сприятливих } \\
\text { міжособистісних стосунків у } \\
\text { колективі }\end{array}$ & $\begin{array}{lrrr}\text { Створення } & \text { умов для успішного налагодження } \\
\text { вчителями спілкування та встановлення контакту } 3 \\
\text { колегами } \\
\text { са } \\
\text { стосунків учми, формування позитивних } \\
\text { ситуацій. }\end{array}$ & 12,5 \\
\hline 2. & $\begin{array}{l}\text { Створення умов для } \\
\text { розвитку умінь, пов'язаних } 3 \\
\text { урахуванням психологічних } \\
\text { особливостей людей }\end{array}$ & $\begin{array}{l}\text { Створення умов для розвитку умінь, пов'язаних } 3 \\
\text { урахуванням психологічних особливостей учнів. }\end{array}$ & 8,6 \\
\hline 3. & $\begin{array}{lr}\text { Забезпечення } & \text { професійного } \\
\text { визнання } & \text { вчителів, } \\
\text { самореалізації } & \text { та } \\
\text { вдосконалення } & \end{array}$ & $\begin{array}{l}\text { Забезпечення умов для знаходження вчителем } \\
\text { свого місця у педагогічному колективі, визнання } \\
\text { вчителя колективом учнів та вчителів; актуалізації } \\
\text { потреби у самовдосконаленні. }\end{array}$ & 5,4 \\
\hline
\end{tabular}

Зазначимо, що нами окремо були проаналізовані труднощі, які, на думку керівників шкіл, виникають у вчителів з різним педагогічним стажем (див. табл. $3,4,5$ ), а потім на основі цих даних були виведені узагальнюючі показники стосовно труднощів у професійній і соціальнопсихологічній адаптації вчителів (див. табл. 2).

Таблиия 2

Труднощі, які, на думку керівників шкіл, існують у професійній адаптації вчителів з різним педагогічним стажем (у\% від загальної кількості опитаних)

\begin{tabular}{|c|l|l|l|l|l|}
\hline \multirow{2}{*}{ № } & \multirow{2}{*}{$\begin{array}{l}\text { Види труднощів у професійній } \\
\text { адаптації вчителів }\end{array}$} & \multicolumn{4}{|c|}{ Категорії вчителів з різним педагогічним } \\
\cline { 3 - 6 } & до 5 років & $\begin{array}{l}\text { від 6 до до } \\
10 \text { років }\end{array}$ & $\begin{array}{l}\text { від 11 до } \\
20 \text { років }\end{array}$ & $\begin{array}{l}21 \\
\text { і більше } \\
\text { років }\end{array}$ \\
\hline 1. & $\begin{array}{l}\text { Труднощі у власне професійній } \\
\text { адаптації }\end{array}$ & 62,8 & 57,5 & 44,4 & 35,0 \\
\hline 2. & $\begin{array}{l}\text { Труднощі у соціально- } \\
\text { психологічній адаптації }\end{array}$ & 29,5 & 16,4 & 23,0 & 24,0 \\
\hline 3. & Відсутність відповіді & 7,7 & 26,1 & 32,6 & 41,0 \\
\hline
\end{tabular}

Охарактеризуємо насамперед дані щодо узагальнюючих показників. Аналіз наведених в табл. 2 даних дає можливість виявити такі тенденції в розумінні керівниками труднощів, 3 якими зустрічаються вчителі з різним педагогічним стажем.

По-перше, при аналізі труднощів, характерних для категорій вчителів 3 різним педагогічним стажем, переважна більшість опитаних керівників (від 35,0 до 62,8 \%) вказують на труднощі, пов'язані з власне професійною адаптацією вчителів (труднощі, пов'язані безпосередньо 3 місцем роботи вчителя, його професійним розвитком, організаційнометодичними та матеріальними труднощами).

I значно менше керівників шкіл (від 24,5 до 29,5 \%), що становить приблизно лише одну п'яту опитаних, вказують на труднощі, які виникають у соціально-психологічної адаптації вчителів (труднощі, які пов'язані із спілкуванням вчителів та їх міжособистісною взаємодією, особистісними характеристиками). Це свідчить про те, що у процесі підготовки керівників шкіл варто значно більше уділяти увагу питанням, які мають відношення не лише до професійної адаптації вчителів, а й до соціально-психологічної адаптації вчителів.

По-друге, аналіз даних, представлених у табл. 2, свідчить, на нашу думку, що, аналізуючи правильно зміст первинної адаптації, керівники шкіл недостатньо чітко розуміють й 
усвідомлюють зміст вторинної адаптації вчителів. Так, лише 7,7\% опитаних керівників зазначили, що їм важко відповісти на питання стосовно труднощів, з якими зустрічаються у професійній адаптації вчителі з педагогічним стажем до 5 років. Одночасно різко зростає кількість керівників (від 26,1\% до 41,0\%), яким важко було відповісти про труднощі, що виникають у професійній адаптації у вчителів з професійним стажем від 6 до 21 і більше років. Зазначимо, що кількість таких керівників зростає в оцінюванні ними педагогічних працівників, які мають все більший стаж педагогічної роботи (відповідно 26,1, 32,6 і 41,0\%). Це може говорити, що проблеми вторинної адаптації вчителів часто залишаються не до кінця зрозумілими для керівників або не настільки важливими, як проблеми первинної адаптації.

Керівники шкіл загалом правильно вказують на основні зміни в професійній адаптації вчителів, які відбуваються з набуттям останніми педагогічного стажу, наприклад, вказують на трансформацію труднощів, пов'язаних із змістом роботи вчителя, на труднощі, пов'язані 3 професійним зростанням, необхідністю підвищення професійного досвіду. Одночасно варто сказати, що проблеми власне професійної адаптації при аналізі всіх категорій педагогічних працівників виступають на перший план порівняно з проблемами соціально-психологічної адаптації.

Окрім того, в процесі аналізу вторинної адаптації (аналіз педагогічних працівників 3 педагогічним стажем від 6 до 21 років і більше) увага звертається здебільшого на матеріальні труднощі і не називаються повною мірою труднощі, які стосуються різних видів вторинної адаптації (пов'язані із зміною типу освітнього закладу, здійсненням змін в оцінюванні навчальної діяльності учнів, введенням сучасних інформаційно-комп'ютерних технологій, динамічними змінами у психічному розвитку дітей, кризовими етапами в професійному розвитку і професійній кар'єрі вчителів, а також трансформаційними процесами в суспільстві).

Поверховими $\epsilon$, на нашу думку, і уявлення керівників про труднощі щодо психологічної та соціально-психологічної адаптації вчителів. Отримані дані свідчать про недостатній рівень психологічної підготовки керівників шкіл 3 проблем управління професійною адаптації та необхідність впровадження спеціальної програми 3 цього напрямку управління в інститутах післядипломної педагогічної освіти.

Таблиия 3

Труднощі, які, на думку керівників шкіл, існують у професійній адаптащії вчителів з педагогічним стажем від 6 до10 років (у\% від загальної кількості опитаних)

\begin{tabular}{|c|c|c|c|}
\hline № & $\begin{array}{l}\text { Труднощі професійної } \\
\text { адаптації вчителів }\end{array}$ & $\begin{array}{l}\text { Сутність труднощів в професійній } \\
\text { адаптації вчителів }\end{array}$ & $\%$ \\
\hline \multicolumn{3}{|c|}{ І. Труднощі, які пов’язані з власне професійною адаптацією вчителів } & 57,5 \\
\hline 1. & Матеріальні труднощі & $\begin{array}{l}\text { Низький рівень матеріального забезпечення; } \\
\text { недостатня матеріально-технічна база школи. }\end{array}$ & 18,0 \\
\hline 2. & Методичні труднощі & $\begin{array}{l}\text { Методичне забезпечення не } \\
\text { «змінюватись» пстигає } \\
\text { методик; труднощі в в обранні методик; } \\
\text { складність в організації нестандартних форм } \\
\text { роботи. }\end{array}$ & 14,8 \\
\hline 3. & $\begin{array}{lr}\text { Tруднощі, } & \text { пов'язані } \\
\text { професійним } & \text { розвитком } \\
\text { вчителя } & \end{array}$ & $\begin{array}{l}\text { Складнощі з поглибленням професійних } \\
\text { навичок, підвищенням професійного досвіду; } \\
\text { труднощі професійного зростання. }\end{array}$ & 13,1 \\
\hline 4. & Організаційні труднощі & $\begin{array}{lrr}\text { Відсутність допомоги } \\
\text { достатніх умов для праці. }\end{array}$ & 6,6 \\
\hline 5. & $\begin{array}{l}\text { Труднощі інформаційного } \\
\text { забезпечення }\end{array}$ & $\begin{array}{lll}\text { Відсутність } & \text { достатнього } & \text { інформаційного } \\
\text { забезпечення. } & & \end{array}$ & 5,0 \\
\hline \multicolumn{3}{|c|}{ II. Труднощі, які відносяться до соціально-психологічної адаптації вчителів } & 16,4 \\
\hline 1. & $\begin{array}{l}\text { Труднощі, пов'язані } \\
\text { особистісними } \\
\text { характеристиками }\end{array}$ & $\begin{array}{l}\text { Нестриманість; недостатня відповідальність; } \\
\text { ригідність мислення; відсутність прогресивних } \\
\text { прагнень та інноваційних підходів; конфлікт } \\
\text { між «хочу» та «можу». }\end{array}$ & 8,2 \\
\hline
\end{tabular}


МЕДЖМЕНТ ОСВІТИ

\begin{tabular}{|c|c|c|c|}
\hline 2. & $\begin{array}{ll}\text { Труднощі у спілкуванні } \\
\text { вчителів та } \\
\text { взаємодії }\end{array}$ & $\begin{array}{l}\text { Труднощі у спілкуванні } 3 \text { колегами, } \\
\text { встановленні контактів } 3 \text { батьками, учнями; } \\
\text { надмірна потеба у підтримці } 3 \text { боку } \\
\text { колективу; невміння володіти класом. }\end{array}$ & 8,2 \\
\hline \multicolumn{3}{|c|}{$\begin{array}{c}\text { III. Кількість директорів шкіл, які зазначили, що їм важко відповісти на } \\
\text { поставлене питання }\end{array}$} & 26,1 \\
\hline
\end{tabular}

Табличя 4

Труднощі, які, на думку керівників шкіл, існують у професійній адаптації вчителів з педагогічним стажем 11-20 років (у\% від загальної кількості опитаних)

\begin{tabular}{|c|c|c|c|}
\hline № & $\begin{array}{l}\text { Труднощі професійної } \\
\text { адаптації вчителів }\end{array}$ & $\begin{array}{l}\text { Сутність труднощів в професійній } \\
\text { адаптації вчителів }\end{array}$ & $\%$ \\
\hline 1 & 2 & 3 & 4 \\
\hline \multicolumn{3}{|c|}{ I. Труднощі, які пов’язані з власне професійною адаптацією вчителів } & 44,4 \\
\hline 1. & Матеріальні труднощі & 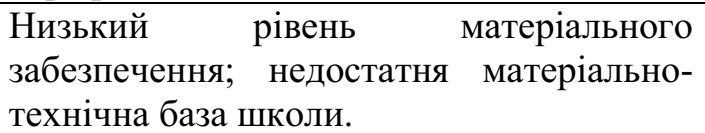 & 18,8 \\
\hline 2. & $\begin{array}{l}\text { Труднощі, } \quad \text { пов'язані } 3 \\
\text { професійним ростом вчителя }\end{array}$ & $\begin{array}{lccc}\text { Труднощі } & 3 & \text { професійним } & \text { ростом; } \\
\text { відсутність безперервної освіти. }\end{array}$ & 9,9 \\
\hline 3. & Методичні труднощі & $\begin{array}{l}\text { Недостатня методична } \\
\text { методичне забезпечення, складності в } \\
\text { оволодінні інноваційними технологіями; } \\
\text { нововведень. }\end{array}$ & 8,4 \\
\hline 4. & $\begin{array}{l}\text { Труднощі } \\
\text { забезпечення }\end{array}$ & $\begin{array}{l}\text { Відсутність достатнього інформаційного } \\
\text { забезпечення. }\end{array}$ & 7,3 \\
\hline \multicolumn{3}{|c|}{ II. Труднощі, які відносяться до соціально-психологічної адаптації вчителів } & 23,0 \\
\hline 1. & $\begin{array}{l}\text { Труднощі, пов'язані } \\
\text { особистісними } \\
\text { характеристиками }\end{array}$ & $\begin{array}{l}\text { Складність характерів; занижена } \\
\text { самооцінка; стереотипне мислення в } \\
\text { оцінки оточуючих; умови праці; нехватка } \\
\text { часу; стереотипне мислення. }\end{array}$ & 10,7 \\
\hline 2. & $\begin{array}{lr}\text { Труднощі } \\
\text { вчителів та } \\
\text { взаємодії }\end{array}$ & $\begin{array}{l}\text { Труднощі } \quad \text { у } \quad \text { взаємовідносини } \quad \text { між } \\
\text { колегами. }\end{array}$ & 5,1 \\
\hline 3. & $\begin{array}{l}\text { Труднощі, пов'язані } \\
\text { мотивацією діяльності }\end{array}$ & $\begin{array}{l}\text { Складність } 3 \text { мотивацією до педагогічної } \\
\text { діяльності; } \quad \text { відсутність } \quad \text { відчуття } \\
\text { задоволення } \quad \text { роботою; необхідність } \\
\text { особливої моральної підтримки } 3 \text { боку } \\
\text { керівництва. }\end{array}$ & 4,7 \\
\hline 4. & $\begin{array}{l}\text { Труднощі } \\
\text { психофізіологічного } \\
\text { характеру }\end{array}$ & $\begin{array}{l}\text { Незадоволеність фізіологічних потреб; } \\
\text { виникнення проблем із здоров`ям. }\end{array}$ & 2,5 \\
\hline \multicolumn{3}{|c|}{$\begin{array}{l}\text { III. Кількість директорів шкіл, які зазначили, що їм важко відповісти на } \\
\text { поставлене питання }\end{array}$} & 32,6 \\
\hline
\end{tabular}

Таблиия 5

Труднощі, які, на думку керівників шкіл, існують у професійній адаптації вчителів $з$ педагогічним стажем 21 і більше років (у\% від загальної кількості опитаних)

\begin{tabular}{|c|c|c|c|}
\hline № & $\begin{array}{c}\text { Труднощі професійної } \\
\text { адаптації вчителів }\end{array}$ & $\begin{array}{c}\text { Сутність труднощів в професійній } \\
\text { адаптації вчителів }\end{array}$ & $\%$ \\
\hline \multicolumn{3}{|c|}{ I. Труднощі, які пов’язані з власне професійною адаптацією вчителів } & 35,0 \\
\hline 1. & $\begin{array}{l}\text { Труднощі, пов'язані } 3 \\
\text { професійним } \\
\text { вчителя }\end{array}$ & $\begin{array}{l}\text { Труднощі, пов’язані з професійним ростом та } \\
\text { підтриманням авторитету, самоосвітою та } \\
\text { обміном професійного досвіду, відчуттям } \\
\text { незадоволеності оцінки своєї праці. }\end{array}$ & 7,8 \\
\hline
\end{tabular}


МЕНЕДЖМЕНТ ОСВІТИ

\begin{tabular}{|c|c|c|c|}
\hline 2. & Матеріальні труднощі & $\begin{array}{l}\text { Tруднощі, пов'язані } 3 \text { низьким } \text { рівнем } \\
\text { матеріального забезпечення. }\end{array}$ & 7,8 \\
\hline 3. & Методичні труднощі & $\begin{array}{l}\text { Складність освоєння нових технологій i } \\
\text { методик; недостатність методичної бази. }\end{array}$ & 7,8 \\
\hline 4. & $\begin{array}{l}\text { Труднощі } \\
\text { інформаційного } \\
\text { забезпечення }\end{array}$ & $\begin{array}{l}\text { Відсутність достатнього } \text { інформаційного } \\
\text { забезпечення. }\end{array}$ & 5,8 \\
\hline 5. & Організаційні труднощі & $\begin{array}{l}\text { Відсутність відповідних умов праці; часта } \\
\text { зміна керівництва; пристосування до нових } \\
\text { умов праці. }\end{array}$ & 5,8 \\
\hline & II. Труднощі, які відносятьсs & до соціально-психологічної адаптації вчителів & 24,0 \\
\hline 1. & $\begin{array}{l}\text { Труднощі, пов'язані } 3 \\
\text { особистісними } \\
\text { характеристиками }\end{array}$ & $\begin{array}{l}\text { Стереотипність мислення щодо форм і } \\
\text { методів роботи; консерватизм; критичність } \\
\text { мислення; перебудова поглядів на сучасне } \\
\text { життя. }\end{array}$ & 12,0 \\
\hline 2. & $\begin{array}{lr}\text { Труднощі } & \text { спілкування } \\
\text { вчителів } & \text { i } \\
\text { міжособистісної взаємодії }\end{array}$ & $\begin{array}{l}\text { Труднощі з взаєморозумінням з учнями та } \\
\text { молодими колегами. }\end{array}$ & 6,0 \\
\hline 3. & $\begin{array}{l}\text { Труднощі } \quad \text { психо- } \\
\text { фізіологічного характеру }\end{array}$ & $\begin{array}{l}\text { Проблеми здоров'я; розлад психічного стану; } \\
\text { вікові проблеми. }\end{array}$ & 4,0 \\
\hline 4. & $\begin{array}{l}\text { Труднощі, пов’язані } 3 \\
\text { мотивацією діяльності }\end{array}$ & Необхідність у підтримці та заохоченні. & 2,0 \\
\hline \multicolumn{3}{|c|}{$\begin{array}{c}\text { III. Кількість директорів шкіл, які зазначили, що їм важко відповісти на } \\
\text { поставлене питання }\end{array}$} & 41,0 \\
\hline
\end{tabular}

Отже, проведене нами дослідження виявило проблеми, які існують у рівні психологічної підготовки більшості керівників шкіл (понад 70,0 \%) до управління професійною адаптацією:

a) професійна адаптація здебільшого розуміється керівниками як односторонній процес засвоєння вчителем існуючих вимог до професійної діяльності (з пристосуванням до специфічних вимог конкретної школи) і не розглядається як процес активного внесення у діяльність школи нових ідей, сучасних підходів у педагогічній діяльності. Як наслідок, не створюються достатні умови для високого рівня активності, творчості вчителів, самовираження їх у фаховій і громадянській діяльності;

б) у процесі управління професійною адаптацією вчителів основна увага керівників акцентується на створенні умов для розвитку професійно-методичних та організаційноситуативних складових професійної адаптації і значно менше - на ії психологічних і соціальнопсихологічних складових;

в) керівники шкіл часто не розглядають управління професійною адаптацією як цілеспрямований цілісний процес, а радше сприймають його як такий, що складається 3 окремих елементів, найчастіше пов'язаних 3 контролем. Також у процесі управління професійною адаптацією практично не враховується складові управління, пов'язані 3 мотивацією вчителів;

г) аналізуючи загалом правильно зміст первинної адаптації, керівники шкіл недостатньо чітко розуміють і усвідомлюють зміст вторинної адаптації вчителів.

Аналіз психолого-управлінської літератури свідчить, що проблема адаптації особистості широко відображена у роботах, присвячених адаптації працівників у промисловості та інших сферах діяльності. Стосовно психологічних особливостей управління професійною адаптацією вчителів у нових соціально-економічних умовах, то ця тема не була раніше предметом спеціального дослідження.

Отримані дані підтверджують висновок про недостатній рівень психологічної підготовки керівників шкіл з проблем управління професійною адаптацією та необхідність впровадження спеціальної програми з цього напрямку управління в інститутах післядипломної педагогічної освіти. 
ЛIТЕРАТУРА

1. Бойко I. І. Соціально-психологічна адаптація підлітка до нових умов навчання: автореф. дис. ... канд. психол. наук. К., 2002. 20 с.

2. Оліфіра Л. Підвищення кваліфікації керівних, педагогічних і науково-педагогічних працівників за накопичувальною системою: відповідь на виклики сучасності. Science Rise. Pedagogical Education. 2018. № 4. C. 43-47. URL: http://nbuv.gov.ua/UJRN/texcped_2018_4_10

3. Нечипоренко К. Сучасні методи навчання як засіб реалізації компетентнісного підходу в освіті. Рідна школа. 2013. № 11. С. 66-69.

4. Жерносєк І. П. Удосконалення науково-методичної роботи в сучасних загальноосвітніх школах, ліцеях і гімназіях: монографія. К.: ІСДО, 2001. 204 с.

5. Гусева В. Проблеми наступності й безперервності освіти: нотатки 3 досвіду. Іноземні мови в сучасній школі. 2012. № 1. С. 39-42.

6. Lipowsky A. Novice teachers' professional adaptation: Ukrainian experience. URL: https://www.academia.edu/30680867/NOVICE_TEACHERS_PROFESSIONAL_ADAPTATION_UKR AINIAN EXPERIENCE

\section{REFERENCES}

1. Bojko I. I. Socialno-psykholohichna adaptatsia pidlitka do novykh umov navchannia: avtoref. dys. ... kand. psykhol. nauk [Socio-psychological adaptation of a teenager to new learning conditions: author's ref. dis. ... cand. psychol sciences: 19.00]. K., 2018. (in Ukranian)

2. Olifira L. Pidvyshhennia kvalifikatsii kerivnykh, pedahohichnykh i naukovo-pedahohichnykh pratsivnykiv za nakopychuvalnoyu systemoyu: vidpovid na vyklyky suchasnosti [Professional development of managerial, pedagogical and scientific-pedagogical workers according to the accumulative system: response to modern challenges]. Science Rise. Pedagogical Education. 2018. № 4. S. 43-47. URL: http://nbuv.gov.ua/UJRN/texcped_2018_4_10 (in Ukranian).

3. Nechyporenko K. Suchasni metody navchannia yak zasib realizatsii kompetentnisnoho pidkhodu v osviti [Modern teaching methods as a means of implementing a competency-based approach in education]. Ridna shkola. 2013. № 11. S. 66-69. (in Ukranian)

4. Zhernosyek I. Udoskonalennia naukovo-metodychnoi roboty v suchasnykh zahalnoosvitnikh shkolakh, liceiakh i gimnaziakh [Improving scientific and methodological work in modern secondary schools, lyceums and gymnasiums]. K.: ISDO, 2001. 204 s. (in Ukranian)

5. Guseva V. Problemy nastupnosti i bezperervnosti osvity: notatky z dosvidu [Problems of continuity and continuity of education: notes from experience]. Inozemni movy v suchasnij shkoli. 2012. № 1. S. 39-42. (in Ukranian)

6. Lipowsky A. Novice teachers' professional adaptation: Ukrainian experience. URL: https://www.academia.edu/30680867/NOVICE_TEACHERS_PROFESSIONAL_ADAPTATION_UKR AINIAN_EXPERIENCE

УДК 378.4 [174.7:347.78]:005.6(477)

DOI 10.25128/2415-3605.20.2. 23

\section{МАРІЯ БОЙКО}

ID ORCID https: //orcid.org/0000-0002-3864-1044 mariyaboykodek@gmail.com кандидат педагогічних наук, доцент Тернопільський національний педагогічний університет імені Володимира Гнатюка вул. Максима Кривоноса, 2, м. Тернопіль

\section{АКАДЕМІЧНА ДОБРОЧЕСНІСТЬ В ОСВІТНЬОМУ ПРОЦЕСІ ПЕДАГОГІЧНОГО УНІВЕРСИТЕТУ: УПРАВЛІНСЬКИЙ АСПЕКТ}

Окреслено проблему академічної доброчесності, визначено основні механізми, інструменти академічної доброчесності, їх відповідність європейським стандартам. Обтрунтовано, що основою формування доброчесного академічного середовища в закладах вищої освіти (ЗВО) є розуміння усіма його учасниками необхідності дотримання принципів академічної доброчесності, на якій базується довіра між університетом та роботодавиями, замовниками освітніх і наукових послуг, спонсорами та іншими стейкхолдерами. Наведено досвід реалізаиї принципів академічної доброчесності $у$ 